\title{
SHALL THE EXECUTIVE AGREEMENT REPLACE THE TREATY?
}

\author{
EDWIN BORCHARD $\dagger$
}

IN recent years many political leaders and publicists have sought to prove that the treaty-making process, requiring the approval of two-thirds of the Senate, has become too cumbersome, inefficient, and "undemocratic." Because of well established "usage," they claim, it has become valid and desirable to substitute for the treaty the executive agreement, preferably without congressional approval or, if necessary, with approval by a majority of Congress. ${ }^{1}$ Advocates of the change point out that some 1300 executive agreements have been concluded during our national history, as contrasted with some 900 treaties. It is not mentioned, however, that up to 1928 only 15 treaties had been rejected by the Senate, usually for good reasons; that 47 were not acted upon; and that while some 160 treaties have been amended by the Senate, ${ }^{2}$ in most cases the changes have benefited the nation.

\section{Bases of the Proposals for Change}

The recent proposals for a change in the Constitution, either with or without benefit of a constitutional amendment, have their origin in several grievances and are said to derive moral support from several recent decisions of the Supreme Court. The modern "reform" movement may be said to have begun with Secretary Hay's denunciation of the Senate for substituting the word "treaty" for the words "special agreement" in the projected arbitration treaties of $1904 .^{3}$ The movement received particular impetus from, and finds its chief present source in, the belief that the twothirds rule prevented American ratification of the Treaty of Versailles, and thus, to use President Wilson's phrase, "broke the heart of the world."

† Justus S. Hotchkiss Professor of Law, Yale Law School.

1. See McCiure, International Executive Agreements (1941) 363. He makes the concession, intended to be generous, that unimportant, non-controversial matters may still be left to treaty and Senate "ratification," but that important and controversial matters become the subject of executive agreement. Id. at 378. Senator Taft remarked in the debate on the Panama Resolution, December 3, 1942, that "As a matter of fact, no treaties of any importance have been submitted to the Senate since $I$ have been a Member of the body." 88 Cong. REC. 9276 (1942).

2. See Dangerfietd, In Defense of the Senate: A Study in Trenty Majung (1933) 256. While only 1.8 per cent of the treaties considered were actually rejected by the Senate, such figures are not conclusive, since these treaties differed in importance.

3. See also 1 Bryce, American Commonwealte (1913) 109. 
But this argument is self-defeating; since, as recent admissions of the unworkability and impropriety of the Treaty of Versailles demonstrate, the Treaty deserved defeat because it was not a treaty of peace but a declaration of war. ${ }^{4}$ Even at the time, informed students realized that it was likely to prove a charter for the production of conflict and war. It must be admitted, however, that only a few Senators, such as the late Robert M. Ia Follette of Wisconsin, placed their opposition to the Treaty on this ground. Nor was ratification thwarted, as it might well have been, because Articles $\mathrm{X}$ and XVI of the Covenant purported to commit the United States to a "blank check" diplomacy, creating an obligation to go to war if necessary in order to maintain the status quo of 1919. The real cause of the Treaty's defeat was that President Wilson requested Democratic Senators not to accept the Lodge reservations, which, it may be added, were acceptable to the British and many students of the subject."

The apprehensions of recent opponents of the two-thirds rule have been aroused by the belief that retention of the rule might prevent the association of the United States with a projected international organization, ${ }^{6}$ of a character still unknown. An effort was made to preserve the Senate prerogative in the Connally Resolution, ${ }^{7}$ which insisted that "constitutional processes" be observed by the United States in joining any peace organization and further provided that any treaty designed to produce international cooperation require approval of two-thirds of the Senate. The counterattack has been vigorous. Professor Corwin has interpreted the term "con-

4. See Bullitt, The Tragedy of Fersailles, Life, MIarch 27, 1944, p. 99. W. D. Herridge, former Canadian Minister to the United States, said that: "Versailles was not a treaty of peace but a declaration of war." Hernivge, Viench Krido of REvoluTION? (1943) 23. See also the late Senator Robert MI. La Follette's contemporary characterization of the "peacemakers" of Versailles as "war makers." Reprinted in The Progressive, June 26, 1944, p. 1, col. 3; and Mrrs. Clare Booth Luce's statement: "This war began at Versailles..." N. Y. Times, June 25, 1944, $\$ 1$, p. 23 , col. 5.

5. See Thomas Lamont's letter to the Editor of the New York: Times: "It was upon the Administration's insistence that the Denocratic Senators voted against acceplance of the Covenant with reservations and thereby automatically voted to defeat the treaty." $N$. $Y$. Times, April 23, 1944, §4, p. 8, col. 6. See Earl Grey's letter to the London Times, which was endorsed by the British and French press, reprinted in N. Y. Times, Feb. 1, 1920, p. 1, col. 8; Flening, The United States and the Lengue of Nations (1932) 311-13. See also Bonsar, Unfinished Business (1944) 27s. For a statement of the negligible part played by the two-thirds rule in the defeat of treaties, see MICClenden, The Two-Thirds Rule irr Senate Action Upon Trcatics, 1789-1901 (1932) 26 A2s. J. I:iT. L. $37,55$.

6. See Colegrore, The American Senate and Worsd Pence (1944); Comini, The Constitution and World Organization (1944) 31 at seq.

7. SEN. Res. No. 192, \&9 CoNG. Rec., Nov. 5, 1943, at 9329; Cozwris, op. cit. suppre note 6, at 51-52. See also the plank on foreign affairs of the Republican Party platform, June 27, 1944, which took the precaution of insisting on Senate consent not only for a "treaty" but also for an "agreement." N. Y. Times, June 28,1944 , p. 1, col. 2-3. 
stitutional processes" in the Connally Resolution as being "non-committal" and has observed that the reference to "any treaty" merely means that if a treaty is made, the Senate will of course have to approve it. ${ }^{8}$ More recently, Congressman Bloom, the Chairman of the Committee on Foreign Affairs of the House of Representatives, has argued that the House should be given a coordinate share with the Senate in the "ratification" of treaties by mere majority vote. ${ }^{0}$ In dismissing the historical fact that the proposal of James Wilson to this effect was defeated in the Constitutional Convention of 1787 , by ten votes to one,$^{10} \mathrm{Mr}$. Bloom alleges that the reasons ${ }^{11}$ for excluding the House have become obsolete and that a more democratic method of treaty approval is now necessary.

Some of the original objections to House participation in the treatymaking process-the necessity for secrecy and speed, the short term of House members, the fluctuating membership-were, as Congressman Bloom urges in his pamphlet, probably valid only so long as the Senate was considered to be an executive council which shared in the actual negotintion of treaties. The fact that the Senate is now merely asked to give "consent" by the constitutional two-thirds vote to treaties previously negotiated by the executive-a fait accompli-does not by itself invalidate the traditional doctrine. At least one of the other reasons originally tunderlying the two-thirds requirement-the desire of the small states to prevent imposition of treaties by a mere majority-retains its cogency. It is well known that some delegates in the ratifying conventions thought the two-thirds requirement too small, rather than too large a protection. More important than the historical reasons, in justifying continuation of decisive Senate control, is perhaps the need for counteracting the recent unprecedented infla-

8. See Corwin, op. cit. supra note 6, at 52. Mr. Corwin objected to the saving clause "or agreement" in the Republican Party platform. N. Y. Times, June 30, 1944, p. 20, col. 6.

9. Bloon, Treaty-Making Power: Fourteen Points showing wiy the theatyMAKING POWER SHOULD BE SHARED BY THE HOUSE OF REPRESENTATIVES (1944).

10. See 2 Farrand, Records of the Federal Convention (1937) 538; Corwin, op. cit. supra note 6, at 33. Mr. Corwin states: "Not until September 7 (1787), ten days before its final adjournment, did the Convention adopt the existing provision [allowing participation by the President] incidentally rejecting by a vote of ten States to one a proposal by Wilson of Pennsylvania that treaties should be made by the President with the advice and consent of the Senate and House of Representatives," Id. at 32. Sce also the rejection of Wilson's proposal, Sept. 8,1787 , by a vote of nine to one, with one divided. 2 FARRAND, op. cit. supra at 548. Various other proposals, to permit a majority alone to concur, to count in all the Senators and to exempt treaties of peace from the two-thirds rule or Presidential consideration, were formally voted down. Id. at $540 \mathrm{et}$ seq.

11. Summarized in Holt, Treaties Defeated by the Senate (1933) 7. Gcorge Washington denied the right of the House to be joined in the making of treaties; sec his communications to the Senate in 1790 and 1792. SEN. Doc. No. 9, 67th Cong,o, 1 st Sess. (1931). 
tion of executive power. A treaty should be convincing enough to command a two-third vote. ${ }^{12}$

Instead of changing the traditional practice so as to permit the House to share in the "ratifying" process, consideration should be given to the desirability of a more fundamental revision of the treaty-maling power, including wider consultation in the actual making of treaties. ${ }^{13}$

\section{HISTORICAL DIFFERENCES}

The Constitution refers only to treaties, giving to them legal effect as the supreme law of the land, and says nothing about Presidential executive agreements. Yet it is apparent that, in dealing with the powers of the states, the Founders were cognizant of the distinction between treaties -which states were prohibited from making-and mere "agreements" or "compacts" with other states or foreign powers, ${ }^{1 / 2}$ which they were permitted to conclude, provided they obtained the consent of Congress. ${ }^{10}$

12. The New York Herald Tribune made the following answer to Professor Corwin's statement that the two-thirds rule has become an "anachronism":

"But if the administration is thinking along these lines it would do well to realize that the point is largely academic. If Congress and the country should overwhelmingly favor a treaty, it is unlikely that an obstruetive Senate minority would persist. The Senate's real power in treaty maling is not merely a mechanical one; it resides in the Senate's ability to force public debate, awalse doubts and secure popular support for other courses than those proposed by the Exceutive. This power is anything but anachronistic, nor is it easily waved saide by juggling precedents or calling treaties by some other name." N. Y. Herald Tribune, April 17, 1944, p. 14, col. 1.

See also Miathews, Anterican Foreign Rechtions: Conduct and Polictes

(1938) 545-46:

"Frequent resort to executive agreements is undoubtedly open to objection. In contrast with treaties, such agreements may be entered into secretly; and the dictates of practical expediency may sometimes afford a plausible excuse for maintaining secrecy where a more far-sighted policy would avoid it. As a rule, international agreements, as well as treaties, should be entered into only in such a way that the salutary influence of public opinion can be brought to bear upon them; the country should not, as a rule, be bound by the stipulations of exceutive agreernents without its knowledge and without opportunity to protest."

13. See the proposals of ex-Ambassador Gibson in his address at Haveriord College. N. Y. Times, June 4, 1944, §1, p. 25, col. 1-2. See also Gibson, Tne Rond ro Fonerg:: PouICY (1944), 179-81. See the pre-war French method of legislative participation in treaty negotiations. Borchard, Democracy in Forcign Policy, Bronson Cutting Lecture, 83 Cosic. Rec. (app.) 538, 541 (1938).

14. See U. S. CoNST. ART. I, \$ 10: "No state shall enter into any treaty, alliance, or confederation... No state shall, without the consent of Congress ... enter into any agreement or compact with another state, or with a foreign power ..." In addition, the word "treaties" is referred to in three separate Articles: concerning negotiations of the national government, id., ART. II, \$2; the jurisdiction of the federal judiciary, id. Arr. III, $\$ 2$; and the supremacy of treaties as the law of the land, $i d .$, Asr. VI.

15. Virginia v. Tennessee, 148 U. S. 503, 519 (1893). 
That the Founders were well aware of this distinction has been further demonstrated by $\mathrm{Mr}$. A. C. Weinfeld, ${ }^{16}$ who has convincingly shown that the framers of both the Articles of Confederation of 1777 and the Constitution of 1787 were under the influence of the great Swiss natural-law jurist and positivist, Emmerich de Vattel. ${ }^{17}$ In his classic work, Le Droit des Gens, Vattel made the following distinctions:

"Section 152. Treaties of Alliance and other public treaties. . . . . A treaty, in Latin foedus, is a pact entered into by sovereigns for the welfare of the State, either in perpetuity or for a considerable length of time.

Section 153. Compacts, agreements or conventions. Pacts which have for their object matters of temporary interest are called agreements, conventions, compacts. They are fulfilled by a single act and not by a continuous performance of acts. When the act in question is performed these pacts are executed once for all; whereas treaties are executory in character and the acts called for must continue as long as the treaty exists.

Section 192. Treaties executed by an act done once for all. Treaties which do not call for continuous acts, but are fulfilled by a single act, and are thus executed once for all, those treaties, unless indeed we prefer to give them another name (see Sec. 153), those conventions, those pacts which are executed by an act done once for all and not by successive acts, are, when once carried out, fully and definitely consummated. If valid, they naturally bring about a permanent and irrevocable state of things. ...." 18

Vattel thus distinguished between agreements embracing continuous executory obligations of projected future duration, which he considered the proper subject of treaties, and pacts having for their object matters of temporary interest or a single act. The latter he considered, though somewhat ambiguously, the appropriate subject of "compacts, agreements or conventions." It is further apparent that Vattel believed that many permanent transactions-such as a cession of territory or peace agreementshould be accomplished by treaty even though consummated by a single act. Mr. Levitan ${ }^{19}$ agrees with Mr. Weinfeld that the term "agreement

16. Weinfeld, What Did the Framers of the Federal Constitution Mcan by "Agrecments or Compacts"? (1936) 3 U. oF CHI. REv. 453.

17. VATTEL, Le DroIt des geNS OU PRINCIPES de la loI Naturelle.

18. See Weinfeld, stupra note 16 , at $459-60$. In a footnote to this quotation Mr. Wcinfeld stated:

"The translation is that accompanying the edition of the Carnegie Endowment for International Peace except that the word 'pacte' I translate as 'pact', 'paction' as 'compact', whereas in that translation 'pacte' is 'compact', 'paction' is 'arrangement'. My translation is equally correct and it brings out more clearly the relationship between Vattel's ideas and the language of the constitutional provisions." Id. at 460 , n. 30.

19. See Levitan, Executive Agreements: A Study of the Executive in the Control of the Forcign Relations of the Unitcd States (1940) 35 ILL. L. Rev. 365, 369. 
or compact" referred to in the Constitution of the United States is derived from the "agreement, convention, compact", or the original French "accords, conventions, pactions," discussed by Tattel.

The "Founding Fathers" formulated this distinction in terms of "important" matters, ${ }^{20}$ which were to be the subject only of formal federal

20. "... The founding fathers felt that the matter of assuming obligations or maling promises to do something in the future for foreign nations vas of sufficient importance to require that the proposal have the support of two-thirds of the Senators . .." Senator Robert Taft in the debate on the Panama Joint Resolution, 88 Co:sc. Rec. 9276 (1942).

With the exception of changes indicated in the above excerpt from Weinfeld's articie, the quotations from Vattel appear in Vatrzi, The LaW of NAtioss or the PRI: crizes of Natural LAw (Carnegie Endowment, ed. 1916), \$§ 152, 153, 192.

A distinction along such lines between treaties and other agreements may bo found elsewhere. The Oxford Dictionary states:

"Treaty ... A contract between, two or more states, relating to peace, truse, alliance, commerce, or other international relation. ... : In the language of modern diplomacy the term "treaty" is restricted to the more important international agreements, especially to those which are the work of a congress, while agreements dealing with subordinate questions are described by the more general term "convention." ... OxFord Dictionary (1926). While not especially informative, this quotation indicates a distinction between important and subordinate matters."

Burdick, The Treaty Making Pou'er (1931-32), 10 For Aframs 265, 279 spealss of a treaty as embracing " 2 matter of important mutual, and therefore of international concern, and no executive officer will care to submit to the Senate for its critical consideration a treaty which has not real international significance" Conwrs, Tue Presurest's Co:rmor of Foretgin Relations (1917) 125, distinguishes between a "durable" treaty and the President's "temporary" power by way of executive agreement. Axzruar. Digest of Pururc International Law Cases 1919-22, Case No. 225, Paris Agreement Case, distinguishes between the "solemn form of treaties" and "informal agreements." See 5 Hictsworsz, Digest of InTernational Law (1943) 397. Assistant Secretary F. B. Sayre in The Corstitutionality of the Trade Agreements Act (1939) 39 CoL. L. REv. 751, 755, says:

"International agreements involving political issues or changes of national policy" and those involving international arrangements of a permanent character usually talie the form of treaties. But international agreements embodying adjustments of detail earrying out well-established national policies and traditions and those involving arrangements of a more or less temporary nature usually take the form of exceutive agreements."

But even in the matter of exempting certain Canadian and United States vessels in sheltered waters on the West Coast from the requirements of the Load Line Convention, when an executive agreement was suggested, Undersecretary Castle stated that the exemption "could not be effected on the part of the United States by an Executive Agreement." 5 HAcKWORTE, op. cit. stipra, at 400.

Undersecretary Grew is quoted as writing in 1926 a note stating that, in addition to the treaty power, "the Executive is empowered without legislative sanction to concluge with foreign governments certain classes of agreements which are not classified as treaties in the sense in which that term is used in the Constitution. These agreements are concluded by virtue of the authority inherent in the Chief Executive under the Constitution, and are confined to subject-matter within the purview of his constitutional authority." Id. at 402. See 1 Blackstone, Cosmansmares (Tueker ed. 1803) (app.) 310: "The former (treaties) relate ordinarily to subjects of great national magnitude and importance, and are often perpetual, or made for a considerable period of time..." Chief 
treaties-known to the Founders as "treaties of peace, of amity and commerce, consular conventions, treaties of navigation" 21 -and "routine" or unimportant questions, ${ }^{22}$ which the States were left free to conclude between themselves by mere agreements.

Circumstances have forced the Executive, in the conduct of military affairs and certain aspects of foreign relations, to conclude-either with or without congressional authorization-numerous agreements with foreign countries covering the movement of armed forces, the adjustment of claims, protocols, tariff and postal agreements, modi vivendi and, as in $1898,{ }^{\prime} 1918$, and 1943, even armistices. The different types of executive agreements will be discussed later. It suffices here to point out that agreements in the past have dealt either with routine questions, within the President's admitted constitutional powers, or have related to matters which the Senate deemed too unimportant for formal treaty procedure, or which Congress had previously authorized. Where the executive agreements perchance related to important questions, as in the case of the famous "Gentlemen's Agreement" of 1907 or the Lansing-Ishii Agreement of 1917—both with Japan - the Senate acquiesced in the conclusion that its approval was not required or would not be insisted upon.

Both writers and courts have made a similar distinction between formal agreements rising to the dignity of treaties and informal agreements of mere administrative character, which are appropriately the subject of executive agreement. ${ }^{23}$ Even ex-Supreme Court Justice and exSenator Sutherland, whose dicta in the Curtiss-Wright ${ }^{24}$ and Belmont ${ }^{25}$

Justice Taney in the famous case of Holmes v. Jennison, 14 Pet. 540, 572 (U. S. 1840), recognized a fundamental distinction between "treaties" and "agreements," citing Vattel in support. See Baldwin, The Entry of the United States into World Politics as One of the Great Pówers (1901) 9 YALE REv. 399, 414. Simeon E. Baldwin speaks of an executive agreement as a "bargain ... something less than a treaty." On the distinction as related to subject-matter, see SEN. Doc. No. 244, 78th Cong., 2d Sess., by Henry S. Fraser.

21. Weinfeld, supra note 16 , at 460 .

22. Moore, Treaties and Executive Agreements (1905) 20 PoL. Scr. Q. 385, 389.

23. Form plays an important part, among other matters, in determining what is a treaty. Professor Garner, Reporter of the Harvard Research Draft on Treaties, makes form the criterion of the treaty and the subject of the rules proposed. The Draft states "There is no treaty apart from the instrument which records its stipulations." (1935) 29 Axr. J. Int. L. (Supp) 691. See also 5 HACkworth, op. cit. supra note 20, at 397. See MCCLURE, op. cit. supra note 1, at 343 ; Four Packages of Cut Diamonds v. United States, 256 Fed. 305, 306 (C. C. A. 2d, 1919) : "Such conventions (postal) are not treaties, because not made by and with the advice and consent of the Senate, and they are not laws, because not enacted by Congress." See the denial of the McClure doctrine that the executive agreement is omnipotent, by Senators Connally, Taft and others. 88 CoNG. REc. 9270, 9276 et seq. (1942). In respect to form it may also be questioned whether the multi-articled agreement with Canada effected by exchange of notes August 18, 1939, as revised later, providing for reciprocal air transportation service, should not have been incorporated in a treaty. See Schnapper, United Nations Agreenients (1944) 149 et seq.

24. United States v. Curtiss-Wright Export Corp., 299 U. S. 304 (1936).

25. United States v. Belmont, 301 U. S. 324 (1937). 
cases gave moral support to the new cult which attributes the force of a treaty to an executive agreement, spoke of a protocol as an example of an executive agreement, "without the formality of a treaty and constituting only a moral obligation."26

While it is true, as Justice Sutherland said, that the precise dividing line between the subject-matter of treaties and executive agreements has never been authoritatively determined, the precedents indicate, as he says, that "international agreements which are not treaties in the full constitutional sense, are perhaps confined to such as affect administrative matters, as distinguished from policies, and those which are of only individual concern, or limited scope and duration, as distinguished from those of general consequence and permanent character." ${ }^{27}$ This traditional distinction in substance, form, and procedure between treaties and executive agreements affords no justification for a belief in their interchangeability.

An executive agreement comes into force on signature, and requires no concurring legislation. If it could repeal acts of Congress, like a treaty, acts of Congress would have a precarious existence. Whatever justification there may be for the executive agreement within its proper scope or for congressional legislation within the authority of Congress, there is no constitutional warrant whatever for the suggestion that the President has an option to submit his compact either to the Senate as a treaty, like the recent petroleum agreement with Great Britain, ${ }^{273}$ or to the Congress for majority approval. The argument for "democracy" is equally invalid. All constitutions require for important acts a decisive majority. Impeachment requires two-thirds of the Senate, and ratification of constitutional Amendments, three-quarters of the states. We hang capital offenders only by a unanimous vote of a jury.

\section{Types of Executive Agreenrents}

There are two major classes of executive agreements: (1) those autthorized by Congress, and (2) those negotiated by the President on his iwn responsibility. By far the greater number fall within the former class.

Agreements Authorized by Congress. Perhaps the largest sub-group in this general category are the several hundred postal agreements and the various reciprocal trade agreements under the Tariff Acts of 1890 and 1897 and the Act of June 12,1934, and its successors.

The extensive delegation of power under the 1934 Tarifi . Ict presents a serious constitutional question. No conclusive answer is provided by the various cases in which the Supreme Court has sustained the delegation under prior tariff acts of the lesser power to determine conclusively whether facts existed to justify imposition of increased or decreased schedules because of "dumping," discriminatory practices by

26. Suthertand, Constitutional Power and Wortd Affairs (1919) 120.

27. Id. at 121.

27a. N. Y. Times, August 9, 1944. 
foreign countries against American exporters, or currency manipulation. ${ }^{28}$ The power delegated under the 1934 Act and its successors is so much more far-reaching that its validity has necessarily been challenged. ${ }^{20}$ However, it is doubtful whether the constitutional question thus posed can be presented to the courts in a justiciable "case or controversy."

Numerous other Acts of Congress have authorized the President, upon finding that a given state of affairs existed, to issue a proclamation carrying into effect all or part of the substantive provisions of the legislation in question. In United States v. Curtiss-Wright Export Corp. ${ }^{80}$ the question was presented whether Congress had acted unconstitutionally in delegating to the President the authority to impose a congressionally authorized embargo on armament shipments to Paraguay and Bolivia, during the Chaco controversy, if he became convinced such action would promote peace between the two countries. The District Court ruled that this constituted an improper delegation of power; the Supreme Court reversed unanimously. Mr. Justice Sutherland's opinion, however, contained a lengthy and uncalled for disquisition on the powers of the federal Government and the executive in foreign relations. ${ }^{31}$

At times Congress has authorized the President to enter into agreements with foreign countries, while reserving to itself the ultimate power to approve or disapprove the agreement actually reached. A good example is the Debt-Funding Agreement Act of February 9, 1922.

Perhaps the most extensive recent delegation of power in this field was that embodied in the Lend-Lease Act of March 11, 1941, ${ }^{82}$ authorizing the President to enter into mutual aid agreements with foreign countries. Under the aegis of this Act, the United States has to date sent abroad over twenty-five billion dollars of American materials.

Although the important American territorial acquisitions of 1803, 1819, $1848,1853,1867$ and 1898 were accomplished by formal treaties, terri-

28. Hampton v. United States, 276 U. S. 394 (1928); Field v. Clark, 143 U. S. 649 (1892).

29. See Fraser, The Constitutionality of the Trade Agrecments Act of 1934 (1937) 31 Proc. Axr. Soc. Int. Law 55. The following articles support constitutionality: Hacleworth, Legal Aspects of the Trade Agreements Act of 1934 (1935) 21 A. B. A. J. 570; Sayre, The Constitutionality of the Trade Agreements Act (1939) 39 CoL. L. REv. 751.

30. 299 U. S. 304 (1936).

31. See page 680 infra.

32. Lend-Lease Act of March 11, 1941, 55 Stat. 31 (1941), 22 U. S. C., $\& 411$ (Supp. 1941-43). The House voted on March 22, 1944, to join the UNRRA. A day later the House Foreign Affairs Committee, in voting to extend the Lend-Lease Act to June 30, 1945, voted unanimously for the Wadsworth Amendment to prohibit the President from making post-war economic or military commitments to any nations in the final Lend-Lease settlements "except in accordance with established constitutional procedure." 90 Cong. Rec., May 4, 1944, at 4080 . The Senate struck out the phrase "in any final settlement," 90 Cong. Rec., May 8, 1944, at 4177 et seq., and the House agreed, 90 Cong. Rec., May 12, 1944 , at 4514. 
tory has under special circumstances been acquired by mere act of Congress. Thus, the annexations of Texas in 1845 and of Hawaii in 1898 were accomplished by joint resolutions of both Houses; in the former case, after a treaty was rejected because Miexico threatened to regard it as a cause for war. In neither case was the act of Congress preceded by an executive agreement; in neither case was the annexation outside the powers of Congress. ${ }^{33}$

Another precedent is found by some writers ${ }^{34}$ in the Joint Resolution of Congress of June 19, 1934, authorizing the President "to accept membership in the International Labor Organization." An invitation was promptly extended to the United States by the organization and was accepted on August 20,1934, through a letter addressed to it by the American Consul at Geneva. But whatever the obligations thus contracted, which are mainly trivial, the method affords no analogy for the general replacement of treaties by executive agreements, since adherence to the International Labor Organization had previously been authorized by Congress, with the unanimous approval of the Senate.

It is also not without interest to note that when Representative Lewis of Maryland, after the so-called World Court protocol failed to receive a two-thirds vote in the Senate in January, 1935, introduced a bill authorizing the President to adhere to the Court protocols, the bill was not seriously supported and remained in committee. A similar fate overtook a joint resolution introduced by Senator Pope on May 7, 1935, to enable the United States to accept membership in the League of Nations. ${ }^{35}$

Agreements Not Authorized by Congress. By virtue of his office as the diplomatic representative of the United States, the President, on numerous occasions, has been obliged to enter into many types of agreements of a less formal character than treaties. As Commander-in-Chief of the Army and Navy, the President has also found it necessary or advisable to send military forces into foreign countries to protect American citizens and has, on his own initiative, entered into armistices and other military protocols and arrangements. The daily work of the Department of State also requires the consummation of numerous understandings and arrangements, variously described as declarations, protocols, exchange of notes, aide-memoire, acts and modi vivendi.

History provides numerous examples of the use of the Presidential prerogative through executive agreements with foreign governments. Thus, various Presidents have adjusted claims against foreign states or submitted them to arbitration and entered into modi vivendi provisionally settling questions whose permanent regulation was left for subsequent

33. See Crandali, Treaties-Their Making and Emrobcensent (2d ed. 1916) §67.

34. Garner, Acts and Joint Resolutions of Congress as Substitutcs for Trcalics (1935)

29 Axr. J. INr. I. 482, 484.

35. Id. at 485. 
treaties, as in the Santo Domingo case of 1905 , and the fisheries adjustment after 1885. In his military capacity as Commander-in-Chief, President McKinley entered into the important Protocol of August 12, 1898, with the French Ambassador, establishing the bases of conditions for peace with Spain-an armistice agreement whose terms were made definitive by the formal Treaty of December 5,1898 . In his capacity as Commanderin-Chief, President Monroe in 1817 signed the Rush-Bagot Agreementlater amended-limiting armaments on the Great Lakes; however, being doubtful of his power, Monroe in 1818 submitted this Agreement to the Senate for approval. ${ }^{36}$.

Agreements benefiting the United States or agreements settling issues without obligating the country, especially if of minor importance, rarely evoke challenge. It is only agreements of a more important character, involving future commitments, that encroach upon the treaty-making power of the Senate. If a substantial opinion in the Senate demands submission of an agreement for approval as a treaty, no President should resolve the doubt in his own favor and defy the Senate and the Constitution.

In so far as lesser examples of the President's exercise of the power of making compacts with foreign countries fall within the normal functions of the Commander-in-Chief of the Army and Navy or the principal diplomatic representative of the United States, they can be sustained as illustrations of the day-to-day activities of government. In so far as they touch questions which properly are the subject of treaties, they can sometimes be justified on the ground that the Senate has acquiesced in such exercise of executive power, finding nothing in the transaction disparaging to its prẹrogatives.

Thus, on a few occasions the President has entered into executive agreements which required the appropriation of money or the transfer of national property by Congress. Here treaty approval has occasionally been short-circuited by the statement that in any event an act of Congress would be necessary to make the appropriation or the transfer. It is probably true that many appropriations have been voted by Congress, which by implication may be deemed to be approvals of earlier executive agreements, such as the acquisition of Horseshoe Reef in 1850 and the more recent destroyer-naval bases exchange. In the matter of transferring several millions of assets from the United States to Panama in 1940, even

36. See Barnetr, International Agreements Without the Advice and Consent of the Senate (1906) 5 Hackworth, op. cit. supra note 19 at 390-433; HYoE, InterNational Law, Chiefly as Interpreted and Applied kY the Untted States (1922) $\$ \S 505-509$; Catudal, Executive Agreements: A Supplement to the Traaty-Making Procedure (1941-42) $10 \mathrm{Gr}_{\mathrm{r}} \mathrm{WW}_{\mathrm{ASH}}$. L. Rev. 653; Levitan, supra note 19, at 376 ct seq.; Moore, supra note 22, at 385-420; Simpson, Legal Aspects of Exccutive Agrccments (1938) 24 Iowa L. Rev. 67. 
the Department of State appears to have thought that the transaction could be justified as an implementation of the 1903 and 1936 Treaties with Panama. ${ }^{37}$

But it is wrong to infer from these examples that the President has the unlimited power, as the "sole organ" of communication with foreign governments, to "conclude" formal agreements, not authorized by Congress, which can bind the United States. The treaty-making power is a definite check upon the President's authority to enter into permanent agreements with foreign countries.

As already observed, the Constitution neither provides a clear definition of the proper subject matter of treaties nor provides for the existence, let alone the scope, of executive agreements. Time and circumstances, however, provide guidance on these questions. We know approximately what kind of questions have historically been embraced by each form and what therefore are their proper spheres.

\section{Senate Stand on its Constitution.l Prerogatives}

It is believed that in the few instances where the President has used his power to make executive agreements in a field important enough to warrant a treaty, as in the case of the destroyer-naval bases transaction, explanation can be found in the apparent Senate acquiescence in the particular assumption of executive power. Thus, the abortive Reciprocity Agreement with Canada of 1911 apparently encroached upon the primary jurisdiction over tariffs of the House of Representatives, but the arrangement was left as a "proposal" only, until congressional approval was obtained. Furthermore, the Senate gave its approval by majority vote, which was a waiver of its treaty prerogative if that were an issue, ${ }^{3 s}$ and, as seems more important, Congress had previously authorized the President to make the Agreement.

Horseshoe Reef was acquired in 1850 by simple executive agreement, but the Senate both before and after joined in approving an appro-

37. Professor Herbert W. Briggs states that the Joint Resolution was in reality based on an uncommunicated executive agreement by exchange of notes dated Yay 18, 1942. Briggs, Treaties, Executive Agreements, and the Panama Joint Resolution of 1943 (1943) 37 Axr. PoL. Sct. Rev. 686. The Department of State seems to regard this as an exceutive agreement, whereas Panama regards it as a treaty. 6 Depr. of StaTE. Bur. No. 152 (1942) 452. The debates in the Senate of December 3 and 4, 1942, where the submitted joint resolution was ultimately approved, 40 to 29 , ES Cosc. REc. 9266-9329 (1942), reveal exceptionally strong protest against the President's use of the executive agrcement to displace the Senate's power in treaty-making. Mrr. Briggs ends his comment with the statement: "... unless the devious methods employed to deprive the Senate of its constitutional authority in the making of treaties are soon abandoned, the nation may be faced with a Senatorial revolt at precisely the critical time when the United States is ealled upon to assume a larger role in the post-war settlement." Briggs, sufro, at 691.

38. 5 HACKWORTH, op. cit. stipra note 20 , at $416-417$. 
priation for a lighthouse there-a condition of the cession; thus it is proper to say the Senate waived its prerogatives. ${ }^{30}$ In the matter of joining the International Labor Organization by joint resolution, the Senate, as was indicated above, gave its approval unanimously. The RootTakahira Agreement of 1908 was communicated to the Senate for its information and received Senate acquiescence. ${ }^{40}$ It is more difficult to justify the 1940 destroyer-naval bases exchange, on legal grounds, but congres. sional acquiescence may be inferred from the almost unanimously approved Lend-Lease Act of March 11, 1941, and from the votes authorizing appropriations for the bases. ${ }^{41}$

In the case of the recent United Nations Relief and Rehabilitation Agreement, calling for a contribution of $\$ 1,350,000,000$ by the United States, a plan was worked out whereby a sub-committee of the Senate Foreign Relations Committee was called into consultation by the State Department before the multilateral agreement was concluded. The consent of the sub-committee to the Agreement was later obtained together with a commitment to recommend to the Senate a waiver of insistence upon a treaty. ${ }^{42}$

That the Senate has on occasion insisted upon a treaty rather than an executive agreement is indicated by President Theodore Roosevelt's effort to arrange for financial administration of the affairs of Santo Domingo by executive agreement. On January 20,1905, such an agreement was signed, but its submission to the Senate was withheld. Between 1905 and 1907, when the treaty was eventually adopted, Theodore Roosevelt administered the arrangement through an executive agreement, realizing the precariousness of its life, but considering necessity paramount. This may be viewed as a modus virendi, analogous to many others concluded in the past. In his Autobiography, President Roosevelt stated:

"The Constitution did not explicity give me power to bring about the necessary agreement with Santo Domingo. But the Constitution did not forbid my doing what I did. I put the agreement into effect, and I continued its execution for two years before the Senate acted; and I would have continued it until the end of my term, if necessary, without any action by Congress. But it was far preferable that there should be action by Congress, so that we might be proceeding under a treaty which was the law of the land and not merely by a direction

39. Levitan, supra note 19 , at 378.

40. Bailey, A Diplonatic History of the Airerican People (1940) 574.

41. For a critical discussion, see Borchard, The Attorney Gentral's Opinion on the Exchange of Destroyers for Naval Bases (1940) 34 AM. J. INT. L. 690; Briggs, Neglected Aspects of the Destroyer Deal (1940) 34 Ax. J. InT. L. 569. See also Lord Lothian's advance criticism, reported in 89 Cong. Rec., March 17, 1943, at 2180-81 (1943), and Professor Corwin's letter to the New York Times. N. Y. Times, Oct. 13, 1940, $\$ 4$, p. 6, col. 5.

42. Colegrove, op. cit. supra note 6, at 28-30. Mr. Colegrove calls this the "Senator Green-Sayre formula" of August 24, 1943. 
of the Chief Executive which would lapse when that particular Executive left office. I therefore did my best to get the Senate to ratify what I had done. There was a good deal of difficulty about it ...." 13

If the Senate in some fashion consents explicitly or impliedly to an executive agreement where the propriety of a mere agreement is doubtful, possibly no objection can be raised except those objections predicated upon the general deficiencies of executive agreements. It is probably also true that if the Senate waives its treaty prerogatives long enough in the face of a continuing Presidential determination to make compacts with foreign countries by executive agreements, the Senate may, by such default, lose its constitutional prerogatives altogether. But this would merely amount to Senate acquiescence in what many students consider an unconstitutional practice and would not therefore be an effective mode of general "ratification."

\section{Weakness of Exicutive Agreearent}

The proposal to make the executive agreement a general substitute for the treaty has many objections. That it is an evasion of the Constitution, characterized as dishonest and dangerous to the entire Constitution and to law, has been admitted by some of the more ardent proponents of the only lawful method of change ${ }^{4}$-a constitutional amendment.

Executive agreements have other dangers and wealnesses which in any case militate against their wide use: First, they permit the President to involve the country in secret agreements, as in case of the secret clause attached to the Lansing-Ishii Agreement of 1917, th the secret Roosevelt-

43. See Corwin, The President: Office and Powers (1941) 237; Theodorc RousevEsT, AN AutobIOGRAPHY (1913) 551.

44. The Chairman of the House Committee on Foreign Affairs suggested that the two major parties insert in their platforms a plank pledging that the peace treaties to be concluded after this war be validated by majority vote of both Houses. This, says the New York Times, is asking both parties "to pledge themselves to disregard the plain wording of the Constitution." In suggesting that "treaties" be called "agreements," the Times says: "This is merely to argue that we can get around the Constitution by conspiring with each other to call a spade by another name," and properly adds, that if that can be done "we can do away with the need for any approval of treaties"; in fact, we can "interpret" the Constitution away. The Times adds: "There is one honest, straightionvard method of change," and that is by constitutional amendment. N. Y. Times, April 17, 1944, p. 22, col. 1. In another editorial, the Times maintained: "This ignoring of a plain constitutional requirement would be a dangerous precedent. It would put in doubt the validity of treaties and international agreements not ratified in the constitutionally preceribed manner." N. Y. Times, Mlay 22, 1944, p. 18, col. 2. See also ColzGsove, op. cit. supro note 6, at $28,31,95,105,110$.

45. This secret clause was not disclosed until the Agreement was repealed at the Washington Conference of 1922. SEx. Doc No. 398, 67th Cong., 4th Sess. (1923) (App. II) 3825. See 2 For. Rez U. S. Dep’t State: The Lasssiac Parzes (1940) 450. 
Katsura Agreement of 1905 recently disclosed by Mr. Dennett, ${ }^{40}$ and the armistice with Italy, the terms of which have not been published. Other examples of such secret control are the second Panama Agreement of May 18, 1942, which was left undisclosed for months, and the RooseveltMackenzie King Defense Agreement of August 18, 1940, only the barest outlines of which seem to have been published. ${ }^{47}$ Secondly, executive agreements either bind a) only the administration that made them, as Theodore Roosevelt and others have thought, or b) are of uncertain duration. In the third place, they may be terminated unilaterally by any future President at any time, without incurring the charge of treaty violation. Fourthly, it is unsafe for the United States or any foreign country to enter into such agreements since, if congressionally approved, they can be congressionally disapproved at any time. In the fifth place, executive agreements do not have the constitutional dignity and force of a treaty, since the Constitution makes no mention of them, but specifically mentions treaties. ${ }^{48}$ In the sixth place, their conscious use as a substitute for treaties gives rise to the charge of constitutional "evasion." 40

46. See Dennett, President Roosevelt's Secret Pact With Japan (1924) 21 Current HISTORY 15.

47. See N. Y. Times, Aug. 19, 1940, p. 1, col. 4 ; N. Y. Times, Aug. 20, 1940, p. 1, col. 1 ; 3 Dept. of State Buld. No. 61 (1940) 154.

48. Every country is charged with knowledge of the obvious parts of its co-contractor's constitutional law. See Fairman, Competence to Bind the State to an Intcrnational Engagement (1936) 30 Ax. J. INT. L. 439.

49. Colegrove states:

"An executive agreement as a substitute for a treaty comes dangerously close to an evasion of the Constitution. The employment of this method would place the post-war pacts on a basis that lacks the traditional validity of treay-law. It would leave an uncertainty in the minds of our allies who would find American commitments resting on an arrangement which is not expressly defined in the Constitution. Colsgrove, op. cit. supra, note 6 , at 31 .

He adds:

"Some doubt exists as to the continuing obligation of executive agreements on succeeding Presidents. For instance, an exchange of notes, stuch as the LansingIshii Agreement of 1917 on Japanese "special interests" in China, has been deemed morally and politically binding upon the administration that negotiated it, but not upon its successor. Some executive agreements, therefore, cannot be considered as a part of the law of the land. ..." Id. at 105.

He concludes:

"The use of executive agreements as a substitute for a peace settlement is a palpable evasion of the fundamental law. The Constitution is clear and unambiguous on the subject of treaties." Id. at 110.

See also Wilcox, The Ratification of International Conventions (1935) 231 :

"Certain considerations arise, however, which limit their extensive use. The idea that the agreements defining executive policy bind only the President under whose direction they are made and may be repudiated by a succeeding administration probably weakens their authority. Furthermore, the agreements made by the express authorization of Congress 'appear to be dependent for their effective- 
Executive agreements are of limited utility because their life and durability are exceedingly precarious. They are either predicated upon an authorizing statute, which may be repealed, or else they are the independent result of Presidential policy. We have already observed that Theodore Roosevelt considered them binding only on the administration which signed them. ${ }^{50}$ This has been the common view, ${ }^{51}$ although its correctness may depend somewhat on the nature of any particular agreement.

In his classic book on the treaty-making power, Charles Henry Butler dismissed the executive agreement as follows:

"It is not, so far as the United States is concerned, a treaty, and does not become the supreme law of the land. How far it is binding upon the national conscience is therefore a political and not a legal question ...

"Such protocols and agreement when first made are binding in a moral sense upon the Executive department of the administration making them; they are not laws nor are they contracts which the legislatures of either party are bound to render effectual by legislation, until after they have assumed legal form by ratification. It is doubtful if they are binding even morally upon any administration other than that which entered into them."

While this was written forty years ago and may not be altogether unchallengeable, it serves to indicate that one of the leading authorities on the subject regarded executive agreements as having a status much inferior to that of treaties. Twenty years later, Justice Sutherland could still speak of executive agreements as having "moral obligation" only. ${ }^{63} \mathrm{Sec}-$ retary of State Lansing considered that the Lansing-Ishii Agreement, though involving an important admission of the priority of Japanese claims in North China, was merely a statement of governmental policy, revocable at will, and not binding on the United States. ${ }^{\text {th }}$

ness upon the authorizing legislation, and are terminable, both nationally and internationally, at the discretion of Congress.' It is also evident that if the President wishes to conclude agreements without the authorization of the Senate or of Congress, they should be of such a nature that he alone is able to execute them."

Secretary of State Gresham, replying to a Brazilian protest against congressional termination of a tariff agreement made under a prior act, denied that they were treaties. For REL. U.S. (U. S. Dep't State 1894) 77. He maintained that they could be unilaterally superseded by Act of Congress.

50. See page 677 supro.

51. See the statement of Senator Taft, 8 Cosc. Rec 9276-9273 (1942).

52. See 2 Butier, The Treatr-Alaking Power of the Uimited States (1902) 370.

53. See SutHerLAND, op. cit. supra note 26 , at 120.

54. See Hearings before Committee on Foreign Relations on Trably of Pcace wills Gernany, 66th Cong., 1st Sess. (1919). President Wilson considered in 1919 that "it was not an agreement at ail, but an 'understanding'." N. Y. Times, July 11, 1919, p. 1, col. 5. See President Harding's view that it was a declaration of policy, 5 Hucrworm, op. cit. stipra note 20, at 431. The Root-Takahira Agreement of 1908, like the Open Deor Notes of 1900 , was also a statement of policy. 
Other recent students have similarly recognized the limitations in usefulness inherent in the very nature of executive agreements. Professor Wright ${ }^{55}$ would limit the power to make executive agreements to matters within the President's independent power of enforcement, which to $\mathrm{Mr}$. Levitan "6 "appears to be the most acceptable explanation." Speaking of congressionally delegated power to enter into agreements with foreign powers, Professor Wright adds that the "arrangement seems to be terminable at discretion of Congress." ${ }^{67}$ Professor Arneson concludes that such agreements bind us as far as national honor is concerned, but do not become a part of our domestic law. ${ }^{58}$

Professor Corwin appears to be among the very few who seem to contend that an executive agreement is as binding as a treaty. "It seems to the writer that Corwin attributes undue importance to the ruling in United States $v$. Pink, ${ }^{60}$ presently to be discussed, which held that the LitvinoffRoosevelt debt assignment of 1933 overruled the previous judicial position, based on the "public policy" of the State of New York, as to the limited effect to be given to Russian confiscatory decrees.

\section{The Impact of Recent Supreme Court Opinions on Executive AGREEMENTS}

Advocates of the proposed constitutional revolution invoke the opinions of the Supreme Court in the Curtiss-Wright, ${ }^{61}$ Belmont ${ }^{62}$ and Pink ${ }^{0 \mathrm{~B}}$ cases, as supporting their views on the binding effect of executive agreements. In considering these cases, it should be remembered that the members of the Supreme Court often inject into their opinions a certain amount of unsupportable dictum, especially in dealing with questions outside their specialties.

In the Curtiss-Wright case, the question involved was whether Congress could constitutionally delegate to the President the power of imposing an impartial arms embargo on Bolivia and Paraguay during the Chaco War, whenever he thought such embargo would contribute to the maintenance or securing of peace between the two countries. In the District Court, ${ }^{\text {os }}$

55. See Wright, The Control of American Foreign Relations (1922) 141, 237, $246,336$.

56. See Levitan, supra note 19, at 394, citing Wrugrt, Domestic Control (1928) 106.

57. See WriGHT, op. cit. supra note 55 , at $233,236$.

58. See Levitan, supra note 19, at 394, quoting Arneson, Elements of Constitutional LAW (1928) 328.

59. See Corwin, op. cit. sispra note 6 , at 43 .

60. 315 U. S. 203 (1942).

61. United States v. Curtiss-Wright Export Corp., 299 U. S. 304 (1936).

62. United States v. Belmont, 301 U. S. 324 (1937).

63. United States v. Pink, 315 U. S. 203 (1942).

64. United States v. Curtiss-Wright Export Corp., 14 F. Supp. 230 (S. D. N. Y. 1936). 
Judge Byers found this delegation of power to the President improper on the ground that it substituted mere presidential opinion for fact-finding. On appeal, the Supreme Court reversed, holding the congressional action perfectly permissible. But the opinion of the Court, written by Mr. Justice Sutherland, did not stop there; it added that in the matter of "negotiation" and "inquiry" the President's powers were plenary and beyond the control of Congress. Justice Sutherland went even further, and delivered a lengthy essay on federal and Presidential powers, which was utterly unnecessary to the case at bar and contains enough ambiguities to afford indefinite sources of argument. He maintained ${ }^{\mathrm{bs}}$ that the federal government-and presumably the President as its "organ"-derived sovereign and negotiating powers in foreign affairs from sources lying in national sovereignty and beyond the Constitution, though he was careful to point out that the Constitution limited the power of the President to bind the nation. These ebullient remarks, which have misled officials of the Department of State, have been severely criticized, notably by the distinguished historian Charles A. Beard, ${ }^{\text {Cb }}$ as well as other scholars, as not justified by constitutional or historical sources.

The Belmont and Pink cases involved the question of whether the Litvinoff assignment of Russian-held assets to this country, as a fund for the payment of American claims against Russia, included the proceeds of the confiscated private property of Russian citizens in the United States. An affirmative answer presupposed that Russia had successfully confiscated such American-situs property and that the United States courts were required to give effect to extraterritorial confiscation. Theretofore the general rule had been in all foreign countries, as well as in the United States, that such confiscations affected only property located in Russia. The further question involved was whether Soviet Russia had conveyed or could convey such property to the United States. The Litvinoff assignment was an inherent condition of Executive recognition.

The Belnnont case arose in 1936 solely on a motion to dismiss, without proof of New York law or policy, or the rights of creditors or stockholders. Instead of emulating the procedure of the two lower courts and granting the motion to dismiss, the Supreme Court remanded the case for further proof of New York policy and for examination of individual claims to the property and the question whether the Fifth Amendment permitted public confiscation by the Russian government or by executive

65. See also SuTHERLAND, op. cit. supro note 26 , at 120 ct seq.

66. See Beard, The Republic (1943) 217-18. In a leamed article, Professor Patterson attacks Justice Sutherland's supposed discovery of the inherent powers of the federal government in internal and external affairs as "(1) contrary to American history; (2) violative of our political theory; (3) unconstitutional, and (4) unnecessary, undemoeratic, and dangerous." Patterson, in re the United States a. Curtiss-II'right Corporation (1944) 22 TEx L. Rev. 286, 297. See also continuation Ibid, 445, and Judge Quarles in 32 GEo. L. J. 375 (1944). 
act of the President. The minority, composed of Justices Stone, Brandeis and Cardozo, joined only in denying the motion to dismiss, which, it is submitted, should have been granted.

In the Pink case in 1941, involving title to a fund held by the New York Superintendent of Insurance after liquidation of the New York branch of a Russian insurance company, Justice Douglas, over the vigorous dissent of Justices Stone and Roberts, broadened the application of Justice Sutherland's dictum in the majority opinion in the Belmont case. Hle held that Russia had purported to confiscate the American-situs property-which is denied by competent students of the subject-and that this private property has been conveyed to the United States, which is also denied by many students in the light of the historical facts. Mr. Justice Douglas held further that the executive agreement, an incident of recognition, prevailed over New York law and policy, in the same manner as a treaty, and that the Fifth Amendment did not prevent the United States from thus cutting off the rights of creditors and stockholders. This opinion, which has been misused by some to sustain the omnipotence of the executive agreement, has itself been criticized by almost all commentators on the subject. ${ }^{67}$

\section{Concluston}

The preceding discussion has indicated the weakness of the arguments for changing the present constitutional prescription regarding the consummation of compacts with foreign nations. While a constitutional amendment is wholly lawful, it does not appear probable that the Gillette Resolution for an amendment, which would reduce the vote necessary for Senate approval of a treaty from two-thirds to a bare majority, ${ }^{\text {is }}$ can even command a majority in the committee so that it can be reported out. Other proposed amendments of similar import have had the same experience.

Proponents of a constitutional amendment do not take account of the new troubles they would encounter if the President did not belong to the

67. See Borchard, Extraterritorial Confiscations (1942) 36 AM. J. INx. L. 275, 282; Comments (1942) 51 Yale L. J. 848; (1942) 5 Detroit L. Rev. 130; (1942) 30 Geo. L. J. 663 ; (1942) 58 L. Q. Rev. 451; (1942) 90 U. of PA. L. Rev. 741. Where the issue does not involve a federal agreement, New York adheres to its view that a foreign confiscation of New York property is intolerable and will not be enforced. Bollack v. Société Gencrale, 263 App. Div. 601, 33 N. Y. S. (2d) 986 (1942). Must we conclude that the foreign confiscation is recognized only when the United States Government becomes the beneficiary of the spoliation?

68. Compare BLoOMr, op. cit. supra note 9, at 15. Commenting upon the reluctance of the Senate to propose a constitutional amendment, the New York Times said editorially: "It may give encouragement to proposals to ignore or by-pass the constitutional requirement by calling treaties mere 'agreements' or 'executive agreements' or by some similar device." N. Y. Times, May 22, 1944, p. 18, col. 2. The Times, as observed, deplores "this ignoring of a plain constitutional requirement" as a "dangerous precedent." Ibid. 
same party as the majority of one or both of the two Houses. They also fail to realize that it might be easier to get a two-thirds vote of approval in the Senate, if a given treaty warrants support, than a majority in a hostile House or Senate, for the nature of the proposed change is such that it might make the congressional "veto" more political than it has been in the past. Furthermore, the assumption that the proposed amendment would be promptly ratified by the states leaves out of account the effective arguments that will be marshalled in opposition to it. ${ }^{69}$ Thus Professor Harry Elmer Barnes in a review of Professor Colgrove's book ${ }^{70}$ remarked recently that "the Senate's treaty power is probably the last remaining bulwark of our national safety-even more, perhaps, than our armed forces-and it should be fought for and maintained at all costs." 71

69. See letter by June Barrows, Ratification of Traaties, N. Y. Times, July 1, 1944, p. 14 , col. 6.

70. Colegrove, loc. cit. supra, note 6 .

71. The Progressive, Miarch 20, 1944, p. 10, col. 2. 